\title{
Sistem Pemilihan Pegawai Terbaik Kantor Camat Siantar Timur Menggunakan AHP
}

\author{
Mhd. Alamin ${ }^{1}$, Eka Irawan ${ }^{2}$, Jaya Tata Hardinata ${ }^{3}$ \\ STIKOM Tunas Bangsa Pematangsiantar, Indonesia \\ Jln. Sudirman Blok A No. 1-3 Pematangsiantar \\ mhdalamin32@gmail.com
}

\begin{abstract}
Abstrak - This study aims to build a decision support system that has the ability to analyze in selecting the best employees in the EAST SIANTAR CUP OFFICE using the Analytical Hierarchy Process (AHP) method. Employees can be compared one to the other from assessment factors and alternatives so that they can give the output of priority intensity values in producing a system that gives an assessment to each employee. This study aims to determine the best employees in the EAST SIANTAR MESSAGE OFFICE. Decision support systems are computer-based information systems (including knowledge-based knowledge management systems) that are used to support decision making in an organization, institution, agency or company. In the process of recruiting the best employees there are several factors that become an assessment, namely from Responsibility, Diligent, honesty and discipline. For the sake of work efficiency and effectiveness, appropriate decision making is needed which aims to build an analysis capability for the best employee selection.
\end{abstract}

Keywords: Office of East Siantar Subdistrict, Decision Support System, Analitycal Hierarchy Process (AHP)

\begin{abstract}
Penelitian ini bertujuan untuk membangun sistem pendukung keputusan yang mempunyai kemampuan menganalisa dalam pemilihan pegawai terbaik di KANTOR CAMAT SIANTAR TIMUR dengan menggunakan metode Analytical Hierarchy Process(AHP). Para pegawai dapat dibandingkan satu dengan yang lainnya dari factor - factor penilaian dan alternatif sehingga dapat memberikan output nilai intensitas prioritas dalam menghasilkan sistem yang memberikan penilaian pada masing-masing pegawai. Penelitian ini bertujuan untuk menentukan pegawai terbaik di KANTOR CAMAT SIANTAR TIMUR. Sistem pendukung keputusan adalah sistem informasi berbasis computer ( termasuk sistem berbasis pengetahuan manajemen pengetahuan) yang dipakai untuk mendukung pengambilan keputusan dalam suatu organisasi,lembaga,instansi atau perusahaan. Pada proses pengekrutan pegawai terbaik ini terdapat beberapa factor yang menjadi penilaian, yaitu dari Tanggung jawab, Rajin, kejujuran dan kedisiplinan. Demi efisiensi dan efektifitas kerja maka pengambilan keputusan yang tepat sangat diperlukan yang bertujuan untuk membangun sebuah kemampuan analisa pemilihan pegawai terbaik.
\end{abstract}

Kata kunci: Kantor Camat Siantar Timur, Sistem Pendukung Keputusan, Analitycal Hierarchy Process (AHP)

\section{PENDAHULUAN}

Dalam kehidupan sehari-hari manusia sering dihadapkan pada suatu momen untuk mengambil sebuah keputusan. Kemampuan mengambil keputusan yang cepat dan cermat akan menjadi kunci keberhasilan dalam persaingan global dan untuk mengambil sebuah keputusan tentu diperluSkan analisis-analisis dan perhitungan yang matang, tergantung dengan banyak sedikitnya kriteria yang 
mempengaruhi permasalahan yang membutuhkan suatu keputusan. Pengambilan suatu keputusan dengan banyak kriteria memerlukan suatu cara penanganan khusus terutama bila kriteria pengambilan keputusan tersebut saling terkait, untuk itu dibutuhkan suatu model sebelum keputusan diambil [1]-[11]. Sumber daya manusia merupakan bagian terpenting bagi tumbuh kembangnya sebuah perusahaan atau instansi. Sebuah instansi dapat berjalan dengan baik tentunya dipengaruhi oleh kualitas sumber daya manusia yang dalam hal ini adalah pegawai yang bekerja di dalam instansi tersebut. Penentuan pegawai terbaik dilakukan tidak hanya dengan cara penunjukan langsung oleh pimpinan atau camat, akan tetapi sebuah instansi harus melakukan penilaian kinerja yang telah dilakukan oleh pegawainya dalam jangka waktu tertentu, dan tentunya akan ada sebuah reward atas keberhasilan yang telah dicapai oleh pegawainya. Hal ini dimaksudkan untuk mendorong setiap pegawai untuk selalu memberikan kinerja yang terbaik bagi instansi dalam melaksanakan tugas dan kewajibanya di instansi.

Berdasarkan latar belakang diatas penulis mengangkat judul "Sistem Pendukung Keputusan Pemilihan Pegawai Terbaik Kantor Camat Siantar Timur Metode Analytical Hierarchy Process". Dari hasil penelitian ini diharapkan dapat membantu pihak instansi untuk dapat menentukan pegawai yang Terbaik di Kantor Camat Siantar Timur.

\section{METODOLOGI PENELITIAN}

Pengumpulan data merupakan proses pengadaan data primer, untuk kebutuhan suatu penelitian. Adapun teknik pengumpulan data dalam penelitian ini yaitu :

a. Penelitian Kepustakaan (Library Research) yaitu memanfaatkan perpustakaan sebagai sarana dalam mengumpulkan data, dengan mempelajari buku - buku sebagai bahan referensi. Hal ini dilakukan dengan membaca tulisan berupa buku dan jurnal yang berkaitan dengan kasus yang penulis angkat.

b. Penelitian Lapangan (Field Work Research) yaitu penelitian yang dilakukan secara langsung dilapangan dengan menggunakan beberapa teknik sebagai berikut:

1. Observasi adalah metode pengumpulan data dengan cara mengadakan pengamatan langsung terhadap berbagai kegiatan yang ada. Hal ini penulis lakukan dengan melakukan pengamatan langsung di lokasi penelitian guna mencari data-data yang diperlukan dalam penelitian ini seperti pengambilan sample alternatif dan kriteria penilaian yang akan diuji.

2. Wawancara adalah proses pengumpulan data atau informasi melalui tatap muka antara pihak penanya (interviewer) dengan pihak yang ditanya atau penjawab (interviewee). Hal ini penulis lakukan dengan bertanya langsung kepada pihak-pihak terkait serta yang bertanggung jawab dalam penilaian Pegawai Terbaik Kantor Camat Siantar Timur.

3. Dokumentasi adalah pengumpulan data yang dilakukan untuk mendapatkan data sekunder dari dokumen-dokumen atau arsip-arsip, yang relavan dengan penelitian ini. Hal ini penulis lakukan dengan membuat dokumen penilaian sample alternatif terhadap kriteria yang sebelumnya telah didiskusikan saat sesi wawancara. 
Data yang digunakan berupa data kriteria dengan pembobotan sesuai dengan rating kepentingannya. Data kriteria yang digunakan dalam menentukan Pegawai Terbaik Kantor Camat Siantar Timur dapat dilihat pada tabel 3.1. berikut.

Tabel 1. Data Kriteria

\begin{tabular}{|c|c|c|}
\hline No & \multicolumn{2}{|c|}{ Kriteria } \\
\hline 1 & $\mathrm{C}_{1}$ & Kejujuran \\
\hline 2 & $\mathrm{C}_{2}$ & Tanggung Jawab \\
\hline 3 & $\mathrm{C}_{3}$ & Rajin \\
\hline 4 & $\mathrm{C}_{4}$ & Kedisiplinan \\
\hline
\end{tabular}

Dengan tingkat kepentingan sebagai berikut :

Tabel 2. Tingkat Kepentingan

\begin{tabular}{|c|c|c|}
\hline No & Nilai & Keterangan \\
\hline 1 & 5 & Sangat Penting \\
\hline 2 & 4 & Penting \\
\hline 3 & 3 & Cukup Penting \\
\hline 4 & 2 & Kurang Penting \\
\hline 5 & 1 & Tidak Penting \\
\hline
\end{tabular}

Sedangkan data sample yang digunakan sebagai alternatif dapat dilihat pada tabel 3.berikut.

Tabel 3. Data Alternatif

\begin{tabular}{|c|c|c|}
\hline No. & Alternatif & Nama Alternatif \\
\hline 1 & $\mathrm{~A}_{1}$ & Hefriyani Syahfitri \\
\hline 2 & $\mathrm{~A}_{2}$ & Tetty Siregar \\
\hline 3 & $\mathrm{~A}_{3}$ & Jupiter Sitepu S,STP \\
\hline 4 & $\mathrm{~A}_{4}$ & Anna Aritonang \\
\hline 5 & $\mathrm{~A}_{5}$ & Zunaidi \\
\hline 6 & $\mathrm{~A}_{6}$ & Sortis Simatupang \\
\hline 7 & $\mathrm{~A}_{7}$ & Ernawati Simagunsong \\
\hline 8 & $\mathrm{~A}_{8}$ & Pranen Sihaloho \\
\hline 9 & $\mathrm{~A}_{9}$ & Eva M.Lubis \\
\hline
\end{tabular}

\section{HASIL DAN PEMBAHASAN}

\subsection{Analisa Permasalahan}

Dalam penentuan pegawai kantor camat terbaik, hanya dilakukan dengan merekomendasikan beberapa orang pegawai yang dianggap memenuhi kriteria penilaian, sehingga diperlukan suatu analisa dan perbandingan penilaian dalam menentukan seorang pegawai kantor camat terbaik, guna membantu para pengambil keputusan berdasarkan penilaian yang dibandingkan.

\subsection{Algoritma AHP}

Sebelum memasuki tahap perhitungan dengan algoritma AHP, penulis terlebih dahulu membuat rating kecocokan alternatif terhadap kriteria yang penulis dapatkan dari hasil observasi dan wawancara yang penulis lakukan sebelumnya. Berikut tabel rating kecocokan yang penulis dapatkan : 
Tabel 4. Rating Kecocokan

\begin{tabular}{|c|c|c|c|c|c|}
\hline \multirow{2}{*}{ No. } & \multirow{2}{*}{ Alternatif } & \multicolumn{5}{|c|}{ Kriteria } \\
\cline { 3 - 6 } & & $\mathbf{C}_{\mathbf{1}}$ & $\mathbf{C}_{\mathbf{2}}$ & $\mathbf{C}_{\mathbf{3}}$ & $\mathbf{C}_{\mathbf{4}}$ \\
\hline 1 & $\mathrm{~A}_{1}$ & 5 & 5 & 4 & 5 \\
\hline 2 & $\mathrm{~A}_{2}$ & 5 & 5 & 3 & 4 \\
\hline 3 & $\mathrm{~A}_{3}$ & 3 & 4 & 5 & 5 \\
\hline 4 & $\mathrm{~A}_{4}$ & 5 & 3 & 3 & 5 \\
\hline 5 & $\mathrm{~A}_{5}$ & 5 & 5 & 4 & 3 \\
\hline 6 & $\mathrm{~A}_{6}$ & 5 & 4 & 3 & 4 \\
\hline 7 & $\mathrm{~A}_{7}$ & 5 & 5 & 3 & 5 \\
\hline 8 & $\mathrm{~A}_{8}$ & 4 & 4 & 4 & 2 \\
\hline 9 & $\mathrm{~A}_{9}$ & 5 & 2 & 3 & 4 \\
\hline
\end{tabular}

Setelah keseluruhan data yang diperlukan seperti kriteria, bobot kriteria, sample alternatif, serta rating kecocokan alternatif terhadap kriteria telah tersedia, maka langkah selanjutnya adalah melakukan perhitungan dengan menggunakan algoritma AHP sebagai berikut :

1. Perhitungan Manual dengan Algoritma AHP

Dalam menentukan pegawai terbaik menggunakan algorima AHP, Penulis menentukan jenis-jenis kriteria yang akan dipertimbangkan. Dalam sistem pendukung keputusan Pemilihan Pegawai Terbaik Kantor Camat Siantar Timur Pematangsiantar, instansi tersebut menetapkan kriteria-kriteria yang digunakan sebagai acuan dalam pengambilan keputusan yaitu Rajin, Tanggung Jawab, Kejujuran, Kedisiplinan. Kemudian keempat kriteria tersebut di bandingkan satu per satu, yang dalam istilah AHP disebut dengan pair-wise comparation.

2. Membangun Hirarki dari Masalah

Berikut adalah hirarki keputusan untuk pemilihan pegawai terbaik kantor camat siantar timur.

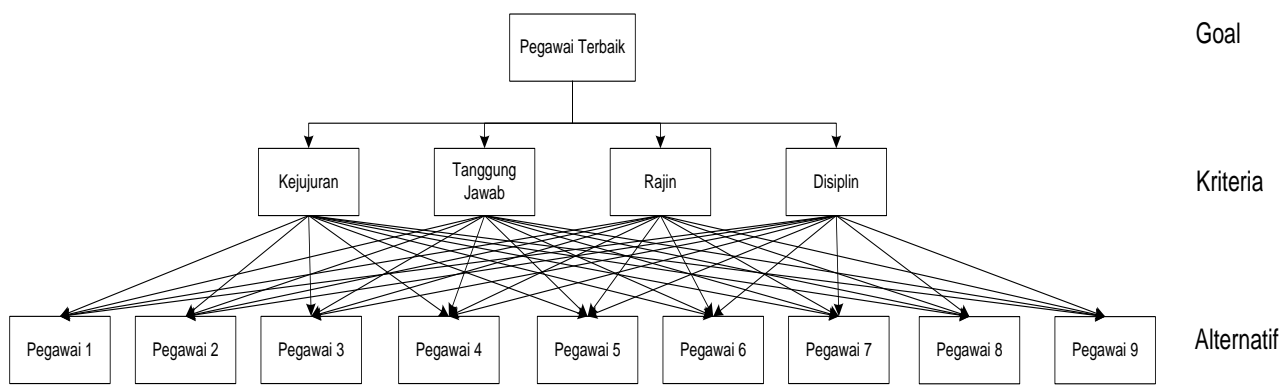

Gambar 1. Hirarki Keputusan

Perhitungan Faktor Pembobotan Hirarki untuk Semua Kriteria

Tabel 5. Skala Penilaian Saaty

\begin{tabular}{|c|l|}
\hline $\begin{array}{c}\text { Intensitas } \\
\text { Kepentingan }\end{array}$ & \multicolumn{1}{c|}{ Keterangan } \\
\hline 1 & Kedua elemen sama pentingnya \\
\hline 3 & Elemen yang satu sedikit lebih penting daripada lainnya \\
\hline 5 & Elemen yang satu esensial atau sangat penting daripada elemen yang \\
\hline
\end{tabular}




\begin{tabular}{|c|l|}
\hline $\begin{array}{c}\text { Intensitas } \\
\text { Kepentingan }\end{array}$ & \multicolumn{1}{c|}{ Keterangan } \\
\hline 7 & lainnya \\
\hline 9 & Satu elemen jelas lebih penting dari elemen lainnya \\
\hline $2,4,6,8$ & Satu elemen mutlak lebih penting daripada elemen yang lainnya \\
\hline Kebalikan & $\begin{array}{l}\text { Nilai-nilai tengah diantara 2 pertimbangan yang berdekatan } \\
\text { Jktifitas j, maka j mempunyai nilai kebalikannya bila dibandingkan } \\
\text { dengan aktifitas i }\end{array}$ \\
\hline
\end{tabular}

Matriks faktor pembobotan hirarki kriteria dibentuk menggunakan Tabel 5. Sehingga didapatlah matriks faktor pembobotan hirarki kriteria sebagai berikut.

Tabel 6. Matriks Faktor Pembobotan Hirarki Kriteria

\begin{tabular}{|c|c|c|c|c|}
\hline Kriteria & $\mathbf{C}_{\mathbf{1}}$ & $\mathbf{C}_{\mathbf{2}}$ & $\mathbf{C}_{\mathbf{3}}$ & $\mathbf{C}_{\mathbf{4}}$ \\
\hline $\mathbf{C}_{\mathbf{1}}$ & 1 & $2 / 1$ & $3 / 1$ & $5 / 1$ \\
\hline $\mathbf{C}_{\boldsymbol{2}}$ & $1 / 2$ & 1 & $2 / 1$ & $3 / 1$ \\
\hline $\mathbf{C}_{\mathbf{3}}$ & $1 / 3$ & $1 / 2$ & 1 & $2 / 1$ \\
\hline $\mathbf{C}_{\mathbf{4}}$ & $1 / 5$ & $1 / 3$ & $1 / 2$ & 1 \\
\hline
\end{tabular}

Selanjutnya matriks pada Tabel 6. disederhanakan menjadi matriks Tabel 7. sebagai berikut.

Tabel 7. Penyederhanaan Matriks Faktor Pembobotan Hirarki Kriteria

\begin{tabular}{|c|c|c|c|c|}
\hline Kriteria & $\mathbf{C}_{\mathbf{1}}$ & $\mathbf{C}_{\mathbf{2}}$ & $\mathbf{C}_{\mathbf{3}}$ & $\mathbf{C}_{\boldsymbol{4}}$ \\
\hline $\mathbf{C}_{\mathbf{1}}$ & 1,00 & 2,00 & 3,00 & 5,00 \\
\hline $\mathbf{C}_{\mathbf{2}}$ & 0,50 & 1,00 & 2,00 & 3,00 \\
\hline $\mathbf{C}_{\mathbf{3}}$ & 0,33 & 0,50 & 1,00 & 2,00 \\
\hline $\mathbf{C}_{\mathbf{4}}$ & 0,20 & 0,33 & 0,50 & 1,00 \\
\hline Total & 2,03 & 3,83 & 6,50 & 11,00 \\
\hline
\end{tabular}

Tabel 8. Normalisasi Matriks Faktor $\left(F_{i j}\right)$

\begin{tabular}{|c|c|c|c|c|}
\hline Kriteria & $\mathbf{C}_{\mathbf{1}}$ & $\mathbf{C}_{\mathbf{2}}$ & $\mathbf{C}_{\mathbf{3}}$ & $\mathbf{C}_{\boldsymbol{4}}$ \\
\hline $\mathbf{C}_{\mathbf{1}}$ & 1,00 & 2,00 & 3,00 & 5,00 \\
\hline $\mathbf{C}_{\boldsymbol{2}}$ & 0,50 & 1,00 & 2,00 & 3,00 \\
\hline $\mathbf{C}_{\mathbf{3}}$ & 0,33 & 0,50 & 1,00 & 2,00 \\
\hline $\mathbf{C}_{\mathbf{4}}$ & 0,20 & 0,33 & 0,50 & 1,00 \\
\hline Total & 2,03 & 3,83 & 6,50 & 11,00 \\
\hline
\end{tabular}
Normalisasi Antar Kriteria Kolom
$1,00 / 3,83=0,261$
C1
$0,50 / 3,83=0,130$
$1,00 / 2,03=0,492$
$0,33 / 3,83=0,087$

$0,50 / 2,03=0,246$

Normalisasi Antar Kriteria Kolom

$0,33 / 2,03=0,164$

C3

$0,20 / 2,03=0,098$

$3,00 / 6,50=0,462$

$\begin{array}{ll}\text { Normalisasi Antar Kriteria Kolom } & 2,00 / 6,50=0,308 \\ \text { C2 } & 1,00 / 6,50=0,154 \\ 2,00 / 3,83=0,522 & 0,50 / 6,50=0,077\end{array}$ 


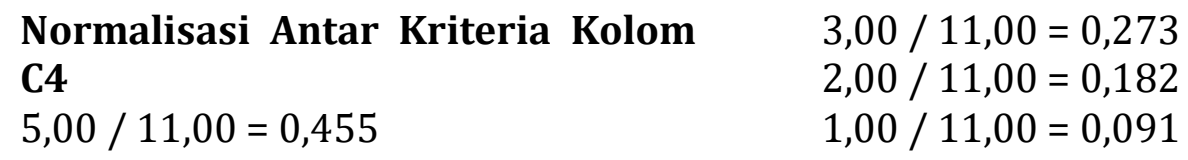

Tabel 9. Hasil Normalisasi Matriks Faktor $\left(F_{i j}\right)$

\begin{tabular}{|c|c|c|c|c|}
\hline $\mathbf{C}$ & $\mathbf{C}_{\boldsymbol{1}}$ & $\mathbf{C}_{\mathbf{2}}$ & $\mathbf{C}_{\mathbf{3}}$ & $\mathbf{C}_{\mathbf{4}}$ \\
\hline $\mathbf{C}_{\boldsymbol{1}}$ & 0,492 & 0,522 & 0,462 & 0,455 \\
\hline $\mathbf{C}_{\boldsymbol{2}}$ & 0,246 & 0,261 & 0,308 & 0,273 \\
\hline $\mathbf{C}_{\mathbf{3}}$ & 0,164 & 0,130 & 0,154 & 0,182 \\
\hline $\mathbf{C}_{\boldsymbol{4}}$ & 0,098 & 0,087 & 0,077 & 0,091 \\
\hline Jumlah & 1,000 & 1,000 & 1,000 & 1,000 \\
\hline
\end{tabular}

Menghitung eigen vector

$$
\begin{aligned}
& \mathrm{C} 1=(0,492+0,522+0,462+0,455) / 4=0,4824066 \\
& \mathrm{C} 2=(0,246+0,261+0,308+0,273) / 4=0,2717977 \\
& \mathrm{C} 3=(0,164+0,130+0,154+0,182) / 4=0,1575084 \\
& \mathrm{C} 4=(0,098+0,087+0,077+0,091) / 4=0,0882873
\end{aligned}
$$

Tabel 10. Bobot Faktor $\left(B_{i}\right)$

\begin{tabular}{|c|c|c|}
\hline Faktor & Bobot & Bobot (\%) \\
\hline $\mathbf{C}_{\mathbf{1}}$ & 0,4824066 & $48 \%$ \\
\hline $\mathbf{C}_{\mathbf{2}}$ & 0,2717977 & $27 \%$ \\
\hline $\mathbf{C}_{\mathbf{3}}$ & 0,1575084 & $16 \%$ \\
\hline $\mathbf{C}_{\mathbf{4}}$ & 0,0882873 & $8 \%$ \\
\hline Total & 1 & $100 \%$ \\
\hline
\end{tabular}

Setelah membuat bobot faktor, langkah selanjutnya adalah menghitung weighted sum vector faktor ke-i $\left(W_{i}\right)$, avarage numbers in vector $(\lambda)$, consistency index (CI), consistency ratio (CR).

$$
\begin{aligned}
& W_{1}=\sum_{j=1}^{n} B_{j} * S_{i j} \\
& W_{1}=(1,00 * 0,482)+(2,00 * 0,271)+(3,00 * 0,157)+(5,00 * 0,088) \\
& =1,9399638 \\
& \lambda_{\text {max }}=\frac{\sum_{i=1}^{n} \frac{W_{i}}{B_{j}}}{N} \\
& \lambda_{\text {max }}=\left(\frac{1,9399638}{0,482}\right)+\left(\frac{1,0928798}{0,271}\right)+\left(\frac{0,6307841}{0,157}\right)+\left(\frac{0,3541221}{0,0882873}\right) \\
& =16,058 \\
& =\frac{16,058}{4}=4,015 \\
& C I=\frac{\left(\lambda_{\max }-N\right)}{N-1} \\
& C I=\frac{(4,015-4)}{4-1}=0,0048 \\
& C R=\frac{C I}{R I_{n}}
\end{aligned}
$$




$$
C R=\frac{0,0048}{0,9}=0,005
$$

\section{Tabel 11. IR}

\begin{tabular}{|c|c|}
\hline $\mathbf{n}$ & $\mathbf{R I} / \mathbf{I R}$ \\
\hline 1 & 0,00 \\
\hline 2 & 0,00 \\
\hline 3 & 0,58 \\
\hline 4 & 0,9 \\
\hline 5 & 1,12 \\
\hline 6 & 1,24 \\
\hline 7 & 1,34 \\
\hline 8 & 1,41 \\
\hline 9 & 1,45 \\
\hline 10 & 1,49 \\
\hline 11 & 1,51 \\
\hline 12 & 1,53 \\
\hline 13 & 1,56 \\
\hline 14 & 1,57 \\
\hline 15 & 1,59 \\
\hline
\end{tabular}

Tabel ini yang sudah ditetapkan pada algoritma Ahp dalam mengukur Index Ratio.

Tabel 12. Perhitungan CR untuk Kriteria

\begin{tabular}{|c|c|c|c|c|}
\hline \multicolumn{2}{|c|}{$\mathbf{W}_{\mathbf{i}}$} & $\boldsymbol{\lambda}_{\max }$ & $\mathbf{C I}$ & $\mathbf{C R}$ \\
\hline $\mathrm{W}_{1}$ & 1,9399638 & 4,015 & 0,0048 & 0,005 \\
\cline { 1 - 2 } $\mathrm{W}_{2}$ & 1,0928798 & & & \\
\cline { 1 - 2 } $\mathrm{W}_{3}$ & 0,6307841 & & & \\
\cline { 1 - 2 } $\mathrm{W}_{4}$ & 0,3541221 & & & \\
\hline
\end{tabular}

Karena $C R<0,100$ berarti preferensi responden adalah konsisten. Dengan demikian dapat diperoleh vektor prioritasnya, sebagai berikut. Kemudian membandingkan Setiap Alternatif terhadap pada setiap kriteria untuk menghasilkan eigen vektor.

Tabel 13. Matriks Perbandingan Alternatif Pada Kriteria Kejujuran

\begin{tabular}{|c|c|c|c|c|c|c|c|c|c|}
\hline $\mathbf{A}$ & $\mathbf{A 1}$ & $\mathbf{A 2}$ & $\mathbf{A 3}$ & $\mathbf{A 4}$ & $\mathbf{A 5}$ & $\mathbf{A 6}$ & $\mathbf{A 7}$ & $\mathbf{A 8}$ & $\mathbf{A 9}$ \\
\hline $\mathbf{A 1}$ & 1,00 & 2,00 & 5,00 & 2,00 & 2,00 & 2,00 & 2,00 & 2,00 & 3,00 \\
\hline $\mathbf{A 2}$ & 0,50 & 1,00 & 5,00 & 2,00 & 2,00 & 2,00 & 2,00 & 2,00 & 2,00 \\
\hline $\mathbf{A 3}$ & 0,20 & 0,20 & 1,00 & 0,33 & 0,33 & 0,33 & 0,33 & 0,50 & 0,33 \\
\hline $\mathbf{A 4}$ & 0,50 & 0,50 & 3,00 & 1,00 & 2,00 & 2,00 & 2,00 & 2,00 & 2,00 \\
\hline $\mathbf{A 5}$ & 0,50 & 0,50 & 3,00 & 0,50 & 1,00 & 2,00 & 2,00 & 2,00 & 2,00 \\
\hline $\mathbf{A 6}$ & 0,50 & 0,50 & 3,00 & 0,50 & 0,50 & 1,00 & 2,00 & 2,00 & 2,00 \\
\hline $\mathbf{A 7}$ & 0,50 & 0,50 & 3,00 & 0,50 & 0,50 & 0,50 & 1,00 & 2,00 & 2,00 \\
\hline $\mathbf{A 8}$ & 0,50 & 0,50 & 2,00 & 0,50 & 0,50 & 0,50 & 0,50 & 1,00 & 3,00 \\
\hline $\mathbf{A 9}$ & 0,33 & 0,50 & 3,00 & 0,50 & 0,50 & 0,50 & 0,50 & 0,33 & 1,00 \\
\hline Jumlah & 4,53 & 6,20 & 28,00 & 7,83 & 9,33 & 10,83 & 12,33 & 13,83 & 17,33 \\
\hline
\end{tabular}

Tabel 14. Normalisasi Matriks Perbandingan Alternatif Pada Kriteria Kejujuran dan Eigen Vector

\begin{tabular}{|c|c|c|c|c|c|c|c|c|c|c|}
\hline A & A1 & A2 & A3 & A4 & A5 & A6 & A7 & A8 & A9 & $\begin{array}{c}\text { Eigen } \\
\text { Vector }\end{array}$ \\
\hline
\end{tabular}




\begin{tabular}{|c|c|c|c|c|c|c|c|c|c|c|} 
A1 & 0,221 & 0,323 & 0,179 & 0,255 & 0,214 & 0,185 & 0,162 & 0,145 & 0,173 & 0,206 \\
\hline A2 & 0,110 & 0,161 & 0,179 & 0,255 & 0,214 & 0,185 & 0,162 & 0,145 & 0,115 & 0,170 \\
\hline A3 & 0,044 & 0,032 & 0,036 & 0,043 & 0,036 & 0,031 & 0,027 & 0,036 & 0,019 & 0,034 \\
\hline A4 & 0,110 & 0,081 & 0,107 & 0,128 & 0,214 & 0,185 & 0,162 & 0,145 & 0,115 & 0,139 \\
\hline A5 & 0,110 & 0,081 & 0,107 & 0,064 & 0,107 & 0,185 & 0,162 & 0,145 & 0,115 & 0,120 \\
\hline A6 & 0,110 & 0,081 & 0,107 & 0,064 & 0,054 & 0,092 & 0,162 & 0,145 & 0,115 & 0,103 \\
\hline A7 & 0,110 & 0,081 & 0,107 & 0,064 & 0,054 & 0,046 & 0,081 & 0,145 & 0,115 & 0,089 \\
\hline A8 & 0,110 & 0,081 & 0,071 & 0,064 & 0,054 & 0,046 & 0,041 & 0,072 & 0,173 & 0,079 \\
\hline A9 & 0,074 & 0,081 & 0,107 & 0,064 & 0,054 & 0,046 & 0,041 & 0,024 & 0,058 & 0,061 \\
\hline Jumlah & 1,000 & 1,000 & 1,000 & 1,000 & 1,000 & 1,000 & 1,000 & 1,000 & 1,000 & 1,000 \\
\hline
\end{tabular}

Tabel 15. Matriks Perbandingan Alternatif Pada Kriteria Tanggung Jawab

\begin{tabular}{|c|c|c|c|c|c|c|c|c|c|}
\hline $\mathbf{A}$ & $\mathbf{A 1}$ & $\mathbf{A 2}$ & $\mathbf{A 3}$ & $\mathbf{A 4}$ & $\mathbf{A 5}$ & $\mathbf{A 6}$ & $\mathbf{A 7}$ & $\mathbf{A 8}$ & $\mathbf{A 9}$ \\
\hline $\mathbf{A 1}$ & 1,00 & 2,00 & 2,00 & 3,00 & 2,00 & 2,00 & 2,00 & 2,00 & 3,00 \\
\hline $\mathbf{A 2}$ & 0,50 & 1,00 & 3,00 & 3,00 & 2,00 & 3,00 & 2,00 & 3,00 & 2,00 \\
\hline $\mathbf{A 3}$ & 0,50 & 0,33 & 1,00 & 3,00 & 0,33 & 2,00 & 0,33 & 2,00 & 0,20 \\
\hline $\mathbf{A 4}$ & 0,33 & 0,33 & 0,33 & 1,00 & 0,33 & 0,50 & 0,33 & 0,50 & 2,00 \\
\hline $\mathbf{A 5}$ & 0,50 & 0,50 & 3,00 & 3,00 & 1,00 & 3,00 & 2,00 & 3,00 & 5,00 \\
\hline A6 & 0,50 & 0,33 & 0,50 & 2,00 & 0,33 & 1,00 & 2,00 & 3,00 & 5,00 \\
\hline A7 & 0,50 & 0,50 & 3,00 & 3,00 & 0,50 & 0,50 & 1,00 & 3,00 & 5,00 \\
\hline A8 & 0,50 & 0,33 & 0,50 & 2,00 & 0,33 & 0,33 & 0,33 & 1,00 & 3,00 \\
\hline A9 & 0,33 & 0,50 & 5,00 & 0,50 & 0,20 & 0,20 & 0,20 & 0,33 & 1,00 \\
\hline Jumlah & 4,67 & 5,83 & 18,33 & 20,50 & 7,03 & 12,53 & 10,20 & 17,83 & 26,20 \\
\hline
\end{tabular}

Tabel 16. Normalisasi Matriks Perbandingan Alternatif Pada Kriteria Tanggung Jawab dan Eigen Vector

\begin{tabular}{|c|c|c|c|c|c|c|c|c|c|c|}
\hline A & A1 & A2 & A3 & A4 & A5 & A6 & A7 & A8 & A9 & $\begin{array}{c}\text { Eigen } \\
\text { Vector }\end{array}$ \\
\hline A1 & 0,214 & 0,343 & 0,109 & 0,146 & 0,284 & 0,160 & 0,196 & 0,112 & 0,115 & 0,187 \\
\hline A2 & 0,107 & 0,171 & 0,164 & 0,146 & 0,284 & 0,239 & 0,196 & 0,168 & 0,076 & 0,173 \\
\hline A3 & 0,107 & 0,057 & 0,055 & 0,146 & 0,047 & 0,160 & 0,033 & 0,112 & 0,008 & 0,081 \\
\hline A4 & 0,071 & 0,057 & 0,018 & 0,049 & 0,047 & 0,040 & 0,033 & 0,028 & 0,076 & 0,047 \\
\hline A5 & 0,107 & 0,086 & 0,164 & 0,146 & 0,142 & 0,239 & 0,196 & 0,168 & 0,191 & 0,160 \\
\hline A6 & 0,107 & 0,057 & 0,027 & 0,098 & 0,047 & 0,080 & 0,196 & 0,168 & 0,191 & 0,108 \\
\hline A7 & 0,107 & 0,086 & 0,164 & 0,146 & 0,071 & 0,040 & 0,098 & 0,168 & 0,191 & 0,119 \\
\hline A8 & 0,107 & 0,057 & 0,027 & 0,098 & 0,047 & 0,027 & 0,033 & 0,056 & 0,115 & 0,063 \\
\hline A9 & 0,071 & 0,086 & 0,273 & 0,024 & 0,028 & 0,016 & 0,020 & 0,019 & 0,038 & 0,064 \\
\hline Jumlah & 1,000 & 1,000 & 1,000 & 1,000 & 1,000 & 1,000 & 1,000 & 1,000 & 1,000 & 1,000 \\
\hline
\end{tabular}

Tabel 17. Matriks Perbandingan Alternatif Pada Kriteria Rajin

\begin{tabular}{|c|c|c|c|c|c|c|c|c|c|}
\hline A & A1 & A2 & A3 & A4 & A5 & A6 & A7 & A8 & A9 \\
\hline A1 & 1,00 & 2,00 & 4,00 & 2,00 & 3,00 & 2,00 & 2,00 & 3,00 & 2,00 \\
\hline A2 & 0,50 & 1,00 & 0,33 & 2,00 & 0,50 & 2,00 & 2,00 & 0,50 & 2,00 \\
\hline A3 & 0,25 & 3,00 & 1,00 & 3,00 & 2,00 & 3,00 & 3,00 & 2,00 & 3,00 \\
\hline A4 & 0,50 & 0,50 & 0,33 & 1,00 & 0,33 & 2,00 & 2,00 & 0,33 & 2,00 \\
\hline A5 & 0,33 & 2,00 & 0,50 & 3,00 & 1,00 & 3,00 & 3,00 & 2,00 & 3,00 \\
\hline A6 & 0,50 & 0,50 & 0,33 & 0,50 & 0,33 & 1,00 & 2,00 & 3,00 & 2,00 \\
\hline A7 & 0,50 & 0,50 & 0,33 & 0,50 & 0,33 & 0,50 & 1,00 & 0,33 & 2,00 \\
\hline A8 & 0,33 & 2,00 & 0,50 & 3,00 & 0,50 & 0,33 & 3,00 & 1,00 & 3,00 \\
\hline A9 & 0,50 & 0,50 & 0,33 & 0,50 & 0,33 & 0,50 & 0,50 & 0,33 & 1,00 \\
\hline Jumlah & 4,42 & 12,00 & 7,67 & 15,50 & 8,33 & 14,33 & 18,50 & 12,50 & 20,00 \\
\hline
\end{tabular}


Tabel 18. Normalisasi Matriks Perbandingan Alternatif Pada Kriteria Rajin dan Eigen Vector

\begin{tabular}{|c|c|c|c|c|c|c|c|c|c|c|}
\hline $\mathbf{A}$ & $\mathbf{A 1}$ & $\mathbf{A 2}$ & $\mathbf{A 3}$ & $\mathbf{A 4}$ & $\mathbf{A 5}$ & $\mathbf{A 6}$ & $\mathbf{A 7}$ & $\mathbf{A 8}$ & $\mathbf{A 9}$ & $\begin{array}{l}\text { Eigen } \\
\text { Vector }\end{array}$ \\
\hline $\mathbf{A 1}$ & 0,226 & 0,167 & 0,522 & 0,129 & 0,360 & 0,140 & 0,108 & 0,240 & 0,100 & 0,221 \\
\hline $\mathbf{A 2}$ & 0,113 & 0,083 & 0,043 & 0,129 & 0,060 & 0,140 & 0,108 & 0,040 & 0,100 & 0,091 \\
\hline A3 & 0,057 & 0,250 & 0,130 & 0,194 & 0,240 & 0,209 & 0,162 & 0,160 & 0,150 & 0,172 \\
\hline $\mathbf{A 4}$ & 0,113 & 0,042 & 0,043 & 0,065 & 0,040 & 0,140 & 0,108 & 0,027 & 0,100 & 0,075 \\
\hline $\mathbf{A 5}$ & 0,075 & 0,167 & 0,065 & 0,194 & 0,120 & 0,209 & 0,162 & 0,160 & 0,150 & 0,145 \\
\hline A6 & 0,113 & 0,042 & 0,043 & 0,032 & 0,040 & 0,070 & 0,108 & 0,240 & 0,100 & 0,088 \\
\hline $\mathbf{A 7}$ & 0,113 & 0,042 & 0,043 & 0,032 & 0,040 & 0,035 & 0,054 & 0,027 & 0,100 & 0,054 \\
\hline $\mathbf{A 8}$ & 0,075 & 0,167 & 0,065 & 0,194 & 0,060 & 0,023 & 0,162 & 0,080 & 0,150 & 0,108 \\
\hline A9 & 0,113 & 0,042 & 0,043 & 0,032 & 0,040 & 0,035 & 0,027 & 0,027 & 0,050 & 0,045 \\
\hline Jumlah & 1,000 & 1,000 & 1,000 & 1,000 & 1,000 & 1,000 & 1,000 & 1,000 & 1,000 & 1,000 \\
\hline
\end{tabular}

Tabel 19. Matriks Perbandingan Alternatif Pada Kriteria kedispilinan

\begin{tabular}{|c|c|c|c|c|c|c|c|c|c|}
\hline $\mathbf{A}$ & $\mathbf{A 1}$ & $\mathbf{A 2}$ & $\mathbf{A 3}$ & $\mathbf{A 4}$ & $\mathbf{A 5}$ & $\mathbf{A 6}$ & $\mathbf{A 7}$ & $\mathbf{A 8}$ & $\mathbf{A 9}$ \\
\hline $\mathbf{A 1}$ & 1,00 & 3,00 & 2,00 & 2,00 & 4,00 & 3,00 & 2,00 & 5,00 & 2,00 \\
\hline $\mathbf{A 2}$ & 0,33 & 1,00 & 0,33 & 0,33 & 3,00 & 2,00 & 0,33 & 5,00 & 2,00 \\
\hline $\mathbf{A 3}$ & 0,50 & 3,00 & 1,00 & 2,00 & 4,00 & 3,00 & 2,00 & 5,00 & 2,00 \\
\hline $\mathbf{A 4}$ & 0,50 & 3,00 & 0,50 & 1,00 & 4,00 & 3,00 & 2,00 & 5,00 & 3,00 \\
\hline $\mathbf{A 5}$ & 0,25 & 0,33 & 0,25 & 0,25 & 1,00 & 0,50 & 0,33 & 3,00 & 0,33 \\
\hline $\mathbf{A 6}$ & 0,33 & 0,50 & 0,33 & 0,33 & 2,00 & 1,00 & 0,50 & 3,00 & 2,00 \\
\hline $\mathbf{A 7}$ & 0,50 & 3,00 & 0,50 & 0,50 & 3,00 & 2,00 & 1,00 & 5,00 & 3,00 \\
\hline $\mathbf{A 8}$ & 0,20 & 0,20 & 0,20 & 0,20 & 0,33 & 0,33 & 0,20 & 1,00 & 0,33 \\
\hline $\mathbf{A 9}$ & 0,50 & 0,50 & 0,50 & 0,33 & 3,00 & 0,50 & 0,33 & 3,00 & 1,00 \\
\hline Jumlah & 4,12 & 14,53 & 5,62 & 6,95 & 24,33 & 15,33 & 8,70 & 35,00 & 15,67 \\
\hline
\end{tabular}

Tabel 20. Normalisasi Matriks Perbandingan Alternatif Pada Kriteria kedispilinan dan Eigen Vector

\begin{tabular}{|c|c|c|c|c|c|c|c|c|c|c|}
\hline $\mathbf{C}$ & $\mathbf{A 1}$ & $\mathbf{A 2}$ & $\mathbf{A 3}$ & $\mathbf{A 4}$ & $\mathbf{A 5}$ & $\mathbf{A 6}$ & $\mathbf{A 7}$ & $\mathbf{A 8}$ & $\mathbf{A 9}$ & $\begin{array}{c}\text { Eigen } \\
\text { Vector }\end{array}$ \\
\hline $\mathbf{A 1}$ & 0,243 & 0,206 & 0,356 & 0,288 & 0,164 & 0,196 & 0,230 & 0,143 & 0,128 & 0,217 \\
\hline $\mathbf{A 2}$ & 0,081 & 0,069 & 0,059 & 0,048 & 0,123 & 0,130 & 0,038 & 0,143 & 0,128 & 0,091 \\
\hline $\mathbf{A 3}$ & 0,121 & 0,206 & 0,178 & 0,288 & 0,164 & 0,196 & 0,230 & 0,143 & 0,128 & 0,184 \\
\hline $\mathbf{A 4}$ & 0,121 & 0,206 & 0,089 & 0,144 & 0,164 & 0,196 & 0,230 & 0,143 & 0,191 & 0,165 \\
\hline $\mathbf{A 5}$ & 0,061 & 0,023 & 0,045 & 0,036 & 0,041 & 0,033 & 0,038 & 0,086 & 0,021 & 0,043 \\
\hline $\mathbf{A 6}$ & 0,081 & 0,034 & 0,059 & 0,048 & 0,082 & 0,065 & 0,057 & 0,086 & 0,128 & 0,071 \\
\hline $\mathbf{A 7}$ & 0,121 & 0,206 & 0,089 & 0,072 & 0,123 & 0,130 & 0,115 & 0,143 & 0,191 & 0,132 \\
\hline $\mathbf{A 8}$ & 0,049 & 0,014 & 0,036 & 0,029 & 0,014 & 0,022 & 0,023 & 0,029 & 0,021 & 0,026 \\
\hline A9 & 0,121 & 0,034 & 0,089 & 0,048 & 0,123 & 0,033 & 0,038 & 0,086 & 0,064 & 0,071 \\
\hline Jumlah & 1,000 & 1,000 & 1,000 & 1,000 & 1,000 & 1,000 & 1,000 & 1,000 & 1,000 & 1,000 \\
\hline
\end{tabular}

Tabel 21. Matriks Perbandingan Kriteria dengan Alternatif

\begin{tabular}{|l|c|c|c|c|}
\hline \multicolumn{1}{|c|}{ C } & K1 & K2 & K3 & K4 \\
\hline Hefriyani Syahfitri & 0,206198 & 0,186582 & 0,221277 & 0,217070 \\
\hline Tetty Siregar & 0,169611 & 0,172546 & 0,090744 & 0,091071 \\
\hline Jupiter Sitepu S,STP & 0,033725 & 0,080511 & 0,172450 & 0,183792 \\
\hline Anna Aritonang & 0,138530 & 0,046653 & 0,075242 & 0,165006 \\
\hline Zunaidi & 0,119533 & 0,159947 & 0,144708 & 0,042573 \\
\hline Sortis Sipayung & 0,103324 & 0,107938 & 0,087610 & 0,071215 \\
\hline Ernawati Simagunsong & 0,089187 & 0,118991 & 0,054024 & 0,132428 \\
\hline
\end{tabular}




\begin{tabular}{|l|l|l|l|l|}
\hline Pranen Sihaloho & 0,079092 & 0,062930 & 0,108480 & 0,026112 \\
\hline Eva M.Lubis & 0,060800 & 0,063902 & 0,045465 & 0,070733 \\
\hline
\end{tabular}

Tabel 22. Hasil Perkalian Matriks

Hasil perkalian didapat dengan mengalikan baris kali kolom dengan mengalikan nilai dari matrik tabel 12 dengan rata- rata pada tabel 10

$\begin{array}{llll}(0,206198 & * & 0,4855) & + \\ (0,186582 & * & 0,1343) & + \\ (0,221277 & * & 0,1070) & + \\ 0,217070 & * & 0,2731) & = \\ 0,204201269 & & \end{array}$

\begin{tabular}{|c|c|c|c|c|c|c|}
\hline K1 & K2 & K3 & K4 & \multirow{8}{*}{$\mathrm{x}$} & $x($ rata-rata $)$ & $\begin{array}{c}\text { Berikut Hasil Perkalian } \\
\text { Matriks }\end{array}$ \\
\hline 0,206198 & 0,186582 & 0,221277 & 0,217070 & & 0,4824 & 0,204201269 \\
\hline 0,169611 & 0,172546 & 0,090744 & 0,091071 & & 0,2718 & 0,151052408 \\
\hline 0,033725 & 0,080511 & 0,172450 & 0,183792 & & 0,1575 & 0,081541071 \\
\hline 0,138530 & 0,046653 & 0,075242 & 0,165006 & & 0,0883 & 0,105926926 \\
\hline 0,119533 & 0,159947 & 0,144708 & 0,042573 & & & 0,127687833 \\
\hline 0,103324 & 0,107938 & 0,087610 & 0,071215 & & & 0,099268156 \\
\hline 0,089187 & 0,118991 & 0,054024 & 0,132428 & & & 0,095566818 \\
\hline 0,079092 & 0,062930 & 0,108480 & 0,026112 & & & 0,074650584 \\
\hline 0,060800 & 0,063902 & 0,045465 & 0,070733 & & & 0,060104936 \\
\hline
\end{tabular}

Tabel 23. Hasil Perangkingan Antar Alternatif

\begin{tabular}{|c|c|l|}
\hline Berikut Hasil Perkalian Matriks & Rank & Nama Pegawai \\
\hline 0,204201269 & 1 & Hefriyani Syahfitri \\
\hline 0,151052408 & 2 & Tetty Siregar \\
\hline 0,081541071 & 7 & Jupiter Sitepu S,STP \\
\hline 0,105926926 & 4 & Anna Aritonang \\
\hline 0,127687833 & 3 & Zunaidi \\
\hline 0,099268156 & 5 & Sortis Sipayung \\
\hline 0,095566818 & 6 & Ernawati Simagunsong \\
\hline 0,074650584 & 8 & Pranen Sihaloho \\
\hline 0,060104936 & 9 & Eva M.Lubis \\
\hline
\end{tabular}

Berdasarkan hasil diatas, dapat ditarik kesimpulan sementara yaitu:

a. Alternatif A1 menjadi alternatif terpilih.

b. Hasil perhitungan algoritma AHP lebih real karena memiliki selisih nilai antar alternatif.

c. Algoritma AHP sangat baik digunakan untuk melihat perangkingan alternatif.

\section{Kesimpulan}

Berdasarkan uraian yang telah di paparkan bab demi bab dari skripsi yang penulis buat, penulis dapat menyimpulkan bahwa :

a. Sistem yang dibangun algoritma AHP dalam menentukan Pemilihan Pegawai Terbaik Kantor Camat Siantar Timur merupakan sistem berbasis web dengan menggunakan aplikasi Macromedia Dreamweaver CS 6.0 dan MySQL Server.

b. Hasil akhir yang diperoleh baik menggunakan perhitungan secara manual maupun secara komputerisasi menunjukkan hasil yang sama, yaitu alternatif $A_{1}$ yang terpilih sebagai alternatif terbaik dalam Pemilihan Pegawai Terbaik Kantor Camat Siantar Timur. 
c. Bilangan real yang dihasilkan oleh perhitungan menggunakan algoritma AHP akan mampu menampilkan selisih antar alternatif yang dibandingkan sehingga kemungkinan hasil yang diperoleh sama menjadi lebih kecil.

Beberapa saran yang dapat penulis berikan yang nantinya dapat digunakan untuk mengembangkan penelitian ini adalah sebagai berikut:

1. Penelitian ini hanya dikhususkan algoritma AHP dalam menentukan Pemilihan Pegawai Terbaik Kantor Camat Siantar Timur, sehingga penulisan ini dapat dijadikan sebagai referensi terkait dengan algoritma yang dibandingkan maupun tentang kasus yang diangkat.

2. Penelitian ini menggunakan sembilan alternatif dan empat kriteria, dan masih dapat dikembangkan baik dari segi alternatif maupun segi kriteria yang dibandingkan untuk mendapatkan data yang komplek serta hasil yang maksimal.

\section{DAFTAR PUSTAKA}

[1] T. Imandasari, A. Wanto, and A. P. Windarto, "Analisis Pengambilan Keputusan Dalam Menentukan Mahasiswa PKL Menggunakan Metode PROMETHEE," Jurnal Riset Komputer (JURIKOM), vol. 5, no. 3, pp. 234-239, 2018.

[2] A. Wanto and E. Kurniawan, "Seleksi Penerimaan Asisten Laboratorium Menggunakan Algoritma AHP Pada AMIK-STIKOM Tunas Bangsa Pematangsiantar," Jurnal Informatika dan Komputer (JIKO), vol. 3, no. 1, pp. 11-18, 2018.

[3] A. Wanto and H. Damanik, "Analisis Penerapan Sistem Pendukung Keputusan Terhadap Seleksi Penerima Beasiswa BBM (Bantuan Belajar Mahasiswa) Pada Perguruan Tinggi Menggunakan Metode Simple Additive Weighting (SAW) (Studi Kasus : AMIK Tunas Bangsa Pematangsiantar)," in Seminar Nasional Rekayasa (SNTR) II, 2015, no. 2, pp. 323-333.

[4] M. Widyasuti, A. Wanto, D. Hartama, and E. Purwanto, "Rekomendasi Penjualan Aksesoris Handphone Menggunakan Metode Analitycal Hierarchy Process (AHP)," Konferensi Nasional Teknologi Informasi dan Komputer, vol. 1, no. 1, pp. 27-32, 2017.

[5] S. Sundari, A. Wanto, Saifullah, and I. Gunawan, "Sistem Pendukung Keputusan Dengan Menggunakan Metode Electre Dalam Merekomendasikan Dosen Berprestasi Bidang Ilmu Komputer (Study Kasus di AMIK \& STIKOM Tunas Bangsa)," in Seminar Nasional Multi Disiplin Ilmu, 2017, pp. 1-6.

[6] R. A. Hutasoit, S. Solikhun, and A. Wanto, "Analisa Pemilihan Barista dengan Menggunakan Metode TOPSIS (Studi Kasus: Mo Coffee)," KOMIK (Konferensi Nasional Teknologi Informasi dan Komputer), vol. 2, no. 1, pp. 256-262, 2018.

[7] N. Rofiqo, A. P. Windarto, and A. Wanto, "Penerapan Metode VIKOR Pada Faktor Penyebab Rendahnya Minat Mahasiswa Dalam Menulis Artikel Ilmiah," Seminar Nasional Sains \& Teknologi Informasi (SENSASI), vol. 1, no. 1, pp. 228-237, 2018.

[8] L. P. Purba, A. P. Windarto, and A. Wanto, "Faktor Terbesar Rendahnya Minat Ber-KB (Keluarga Berencana) dengan Metode ELECTRE II," Seminar Nasional Sains \& Teknologi Informasi (SENSASI), vol. 1, no. 1, pp. 369-374, 2018.

[9] M. Masitha, D. Hartama, and A. Wanto, "Analisa Metode (AHP) pada Pembelian Sepatu Sekolah Berdasarkan Konsumen," Seminar Nasional Sains \& Teknologi Informasi (SENSASI), vol. 1, no. 1, pp. 338-342, 2018.

[10] S. R. Ningsih, D. Hartama, A. Wanto, I. Parlina, and Solikhun, "Penerapan Sistem Pendukung Keputusan Pada Pemilihan Objek Wisata di Simalungun," in Seminar Nasional Teknologi Komputer \& Sains (SAINTEKS), 2019, pp. 731-735.

[11] S. Sundari, S. M. Sinaga, I. S. Damanik, and A. Wanto, "Sistem Pendukung Keputusan Pemilihan Peserta Olimpiade Matematika SMA Swasta Teladan Pematangsiantar Dengan Metode Electre," in Seminar Nasional Teknologi Komputer \& Sains (SAINTEKS), 2019, pp. 793-799. 